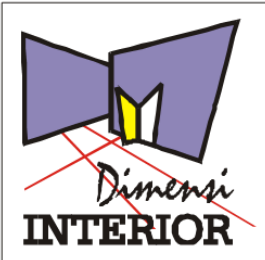

http//dimensiinterior petra.acid

\title{
Implementasi Konsep "Bound to Nature" pada Perancangan Interior Mangrove Edu-Tourism Centre di Surabaya
}

\author{
David Ardi Laksono | Diana Thamrin | Lucky Basuki \\ Program Studi Desain Interior, Universitas Kristen Petra, Surabaya \\ Email: davidliem21@gmail.com
}

\begin{abstract}
ABSTRAK
Masalah yang menjadi latar belakang dari perancangan ini adalah masyarakat Surabaya kurang mengenal keberadaan ekosistem mangrove dan pengembangan potensi produk olahannya oleh UKM (Usaha Kecil Menengah) lokal di Surabaya. Disisi lain juga karena kurang terjangkaunya dan tidak memadainya wadah pendukung kegiatan tersebut. Tujuan dari Perancangan ini adalah menyediakan wadah alternatif untuk berkumpul dan mengenalkan kepada generasi millennial agar dapat memahami dan bereksperimen dengan potensi mangrove, melalui pendekatan edukatif, rekreatif, interaktif dan konten lokal, serta mensejahterakan masyarakat mangrove. Metode perancangan yang digunakan adalah metode Disney yang terdiri dari 4 tahap, yakni spectator view, dreamers view, realists view, dan critics view. Hasil perancangan adalah sebuah Mangrove Edu-Tourism Centre berkonsep Bound to Nature, dengan fasilitas ruang terbuka telaga, stal makanan, area informasi dan tunggu, galeri produk UKM, studio workshop, studio pembibitan, ruang staf, area santai, kubah konservatorial, dek atraktif, dan rumah teh. Penulis berharap melalui perancangan ini dapat memberi solusi sekaligus sebagai wadah komunitas global, dengan usaha mikro yang berefek makro untuk membantu mengelola dan menyelamatkan lingkungan mangrove di Surabaya.
\end{abstract}

Kata Kunci: Interior, Mangrove, Edu-Wisata, Surabaya.

\section{ABSTRACT}

The problem that became the background of this design project is that the people of Surabaya lack knowledge of the existence of the mangrove ecosystem and the development of the product's potential by local SME's (Small and Medium-sized Enterprises) in Surabaya. On the other hand, it is also due to inaccessibility and inadequate space to support these activities. The purpose of this design is to provide an alternative space to gather and introduce to the millennial generation to understand and experiment with the mangrove potential through educative, recreational, interactive, and local content approach, as well as the welfare of mangrove community. The design method used is the Disney method which consists of 4 stages, which is spectator view, dreamers view, realists view, and critics view. The design result is a Mangrove Edu-Tourism Centre with the concept of Bound to Nature, with facilities that include an open space lake, food stall, information and waiting area, SME product gallery, workshop studio, cultivation studio, staff room, lounge area, conservatory dome, sightseeing deck, and teahouse. Through the design yielded in this research, the authors hope that this design could provide solutions as a global community space, with a micro effort that lead to macro effects in assiting the management and preservation of the mangrove environment in Surabaya.

Keywords: Interior, Mangrove, Edu-Tourism, Surabaya

\section{PENDAHULUAN}

Indonesia merupakan negara kepulauan yang dikelilingi banyak jenis tipe hutan hujan tropis. Namun, hanya satu jenis vegetasi hutan pelindung daratan pantai dari kerusakan, yakni hutan mangrove atau mangrove. Sekitar 3 juta hektare hutan mangrove tumbuh di sepanjang 95.000 kilometer pesisir Indonesia, mewakili $23 \%$ dari ekosistem mangrove dunia ${ }^{[1]}$. Ekosistem hutan mangrove berkarakter sangat khas dan unik, paduan kehidupan darat dan air, sehingga sangat strategis karena memiliki potensi kekayaan hayati baik dari segi biologi, ekonomi bahkan pariwisata. Hal ini membuat berbagai pihak ingin memanfaatkan potensi tersebut.
Namun seiring berjalannya waktu, kondisi lingkungan hutan mangrove semakin memprihatinkan akibat ancaman dari kegiatan manusia dan kurangnya kepedulian menyelamatkan lingkungan. Indonesia merupakan negara dengan jumlah sampah yang terbuang ke laut terbesar kedua setelah China. Pembalakan hutan mangrove untuk lahan pembangunan banyak terjadi di Indonesia, kondisi ini juga diperparah dengan minimnya pembibitan dan reboisasi hutan mangrove. Setiap Pulau di Indonesia berperan dalam meningkatnya permasalahan ini, karena jumlah peningkatan penduduk, wisatawan, peningkatan konsumsi produk dan kurangnya kesadaran masyarakat untuk peduli ekosistem mangrove. 


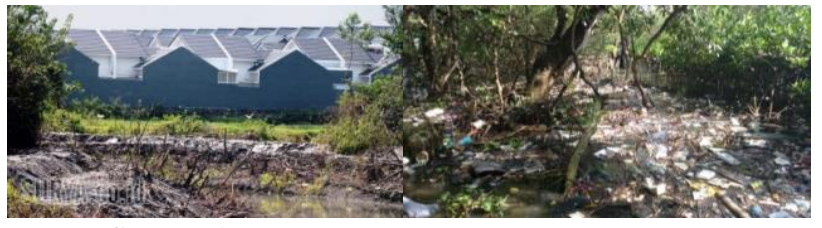

Gambar 1. Kondisi Ekosistem Mangrove pada Kawasan Pamurbaya dan Pantarbaya.

Sumber: https://hariansurya.co.id/HabiburRohman

Salah satunya kerusakan ekosistem mangrove terjadi di Pulau Jawa, yang dihuni sekitar $60 \%$ dari total penduduk Indonesia. Banyak kota besar di pulau Jawa yang berdiri diatas bibir pantai, salah satunya kota Surabaya sebagai kota terbesar kedua di Indonesia. Surabaya memiliki ruang terbuka hijau berupa hutan mangrove yang tersebar sepanjang garis pantai timur Surabaya (Pamurbaya) dan pantai utara Surabaya (Pantarbaya). Pengembangan kawasan hutan konservasi mangrove ini diarahkan untuk perlindungan pantai dari kerusakan. Secara ekologis, area ini juga berfungsi untuk melindungi Surabaya dari abrasi laut, angin ribut, banjir luapan sungai, serta juga berfungsi membantu infiltrasi atau penyerapan air laut ke dalam tanah ${ }^{[2]}$.

Menurut riset PemKot Surabaya (2017), sebagian besar wisatawan, berasal dari luar kota Surabaya, sementara hanya $10-15 \%$ saja masyarakat lokal yang pernah mengunjunginya. Pada Gambar 2, dapat diketahui bahwa keberadaan dan peran mangrove di kawasan konservasi ekowisata mangrove Pamurbaya dan Pantarbaya ini penting bagi masyarakat kota Surabaya sebagai ruang terbuka hijau maupun bagi ekosistem alam. Namun keberadaannya kurang dijaga, karena masih banyak anggota masyarakat yang tidak sadar dan mengetahui manfaat dari mangrove itu sendiri.

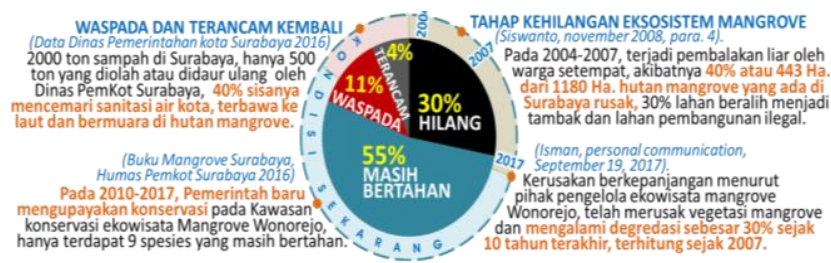

Gambar 2. Bagan Persentase Kondisi Ekosistem Mangrove pada Kawasan Pamurbaya dan Pantarbaya [2]

Oleh karena itu penelitian dan perancangan ini dirasa penting untuk mengkaji latar belakang sebuah wadah perancangan berbasis mangrove edu-tourism centre yang berbeda dari perancangan sebelumnya yang ada, dengan pendekatan nilai edukatif, interaktif, dan rekreatif bagi masyarakat kota Surabaya bahkan dunia, untuk memperkenalkan beragam pembudidayaan mangrove hingga perawatan dan pemanfaatannya pada kawasan konservasi mangrove Pamurbaya dan Pantarbaya. Perancangan ini diharapkan dapat mendukung kembali perlindungan area hutan mangrove yang telah rusak dan juga menghidupkan kembali perekonomian masyarakat disekitar daerah tersebut. Beberapa UKM (Usaha Kecil Menengah) didaerah Pamurbaya dan Pantarbaya banyak memanfaatkan potensi mangrove seperti hasil karya seni dari sampah atau limbah mangrove, produk makanan dan minuman dari tanaman mangrove, serta hasil budidaya tambak.

\section{METODE PERANCANGAN}

Metode perancangan yang digunakan adalah literatur Disney Method yang dirumuskan oleh Robert Dilts pada 1994, yaitu desainer harus melakukan cara berpikir pararel dimana kita diharuskan untuk menganalisa masalah, mengeluarkan ide, mengevaluasi ide, membuat kritik atas apa yang telah dilakukan ${ }^{[3]}$.

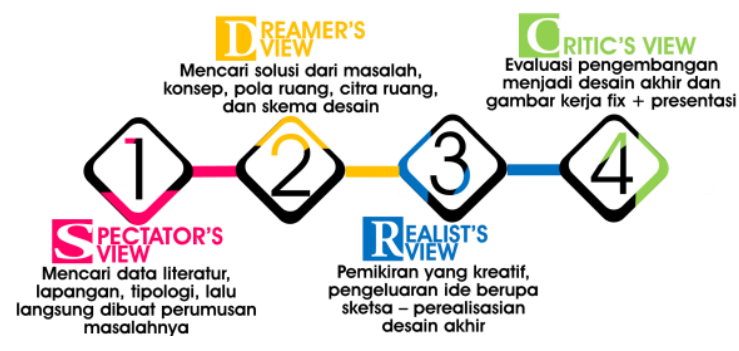

Gambar 3. Bagan Disney Method [3]

Disney method terdiri dari 4 tahap, yang dijelaskan dalam penjabaran berikut, antara lain:

A.Spectator View: Tahap berfikir fakta, data dan eksternal sudut pandang terkait masalah di lapangan. Langkah-langkah yang dilakukan pada tahapan ini antara lain;

- Literature Data, dengan metode mobile diary study, mencari literatur objek perancangan, studi banding untuk dianalisa kelebihan dan kekurangan sebagai bahan pertimbangan.

- Exsisting Data, dengan metode interview (contextual inquiry), yang dapat memberikan data dan keterangan yang diperlukan, baik data fisik maupun data non fisik.

- Comparison of Data, dengan membandingkan beberapa tempat berbasis sejenis, untuk diambil keuntungan beserta kekurangannya, sehingga menjadi acuan dan kesimpulan untuk menghasilkan perancangan yang maksimal.

B.Dreamers View: Tahap befikir dan bermimpi sejauh mungkin, tanpa batasan mengeluarkan ide desain. Langkah-langkah yang dilakukan pada tahapan ini antara lain;

- Solution Dream, pola konsep sebagai solusi desain masalah pada lokasi perancangan, berupa gambaran sketsa tangan.

- Make it Happen, berupa gambaran pencapaian dari mimpi, dengan organization layout plan, furniture plan, citra ruang dalam bentuk tiga dimensi secara computerize, lengkap dengan skema warna dan material yang akan dipakai.

- Reality Dream, dengan gambar desain skalatis atau non-skalatis beserta ukuran yang mudah dipahami khalayak.

C.Realists View: Tahap mengeluarkan ide yang harus mampu direalisasikan. Langkah-langkah yang dilakukan pada tahapan ini antara lain;

- The Details, pemikiran konstruksi dan detail. Perancang memulainya dengan gambaran konstruksi 
dan detail manual melalui sketsa tangan, sebelum pengerjaan computerize.

- Design Execution, dengan gambar presentasi yang lebih matang, sketsa baru bisa menambah pengembangan ide desain akhir. Prototype dapat berupa maket presentasi skalatis agar memberikan suasana dan gambaran nyata dalam bentuk skala.. Serta media presentasi yang menarik.

D.Critics View: Tahap menyelesaikan dan mengubah desain sesuai dengan kritik dan masukan dari proses evaluasi hingga tercipta implementasi hasil desain akhir. Langkah-langkah yang dilakukan pada tahapan ini antara lain;

- Story Telling, perancang mempresentasikan hasil desain untuk mendapatkan kritik dan saran atas solusi desain yang ditawarkan. Hingga muncullah evaluasi dan perbaikan untuk meningkatkan mutu desain menjadi lebih baik.

- Implementation, perancangan Interior Mangrove Edu-Tourism Centre di Surabaya ini dapat memperkuat branding diri dan identitas bagi perancang agar lebih dikenal, sebagai perancang interior dengan keahlian dibidang Edu-Tourism Project. Dengan kemasan showcase product yang dapat ditampilkan dapat berupa maket skalatis, booklet view, presentation board, brosur, plakat banner, video, web-access, dan produk penunjang lainnya.

\section{KAJIAN PUSTAKA}

A. Prinsip Ketata Aturan dan Kriteria Pusat EduTourism

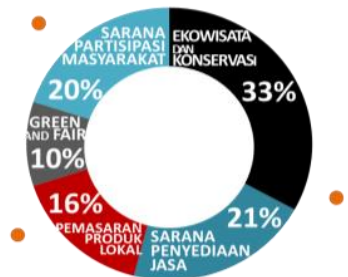

Gambar 4. Bagan Persentase Fokus Prinsip Ketata Aturan dan Kriteria Edu-Tourism [4]

Prinsip dan kriteria Edu-Tourism menurut Kerjasama Direktorat Produk Pariwisata, Direktorat Jenderal Pengembangan Destinasi Pariwisata, Departemen Kebudayaan dan Pariwisata dan WWF-Indonesia tahun 2009 [4] diantaranya:

-Edu-Tourism yang berkesinambungan dengan Ekowisata dan Konservasi, sebagai salah satu program usaha yang sekaligus bisa menjadi strategi konservasi dan dapat membuka alternatif ekonomi bagi masyarakat.

- Edu-Tourism sebagai Sarana dan penyediaan jasa pendukung dalam mengembangkan ekowisata yang bernilai konservasi dan ekonomi tinggi dapat diraih dengan memanfaatkan masyarakat setempat sebagai pemandu informasi.

- Edu-Tourism memahami pemasaran produk lokal setempat dalam mengembangkan pemasaran, strategi pencitraan (branding) dan promosi untuk produk karya masyarakat yang berada di kawasan hutan lindung.

- Edu-Tourism dengan basis Green and Fair dengan memahami kebutuhan fasilitas yang diutamakan bagi pengunjung, selain juga untuk tidak menggunakan lahan dan material yang berasal dari sumber daya alam wilayah konservasi. Konsep Green and Fair diharapkan untuk kepentingan pembangunan berkelanjutan (sustainable) yang lebih baik.

- Edu-Tourism sebagai sarana pengembangan institusi masyarakat lokal dan kemitraan (Prinsip partisipasi masyarakat) diharapkan edu-tourism dapat menjadi lahan bagi para Industri kecil dan masyarakat industri kreatif setempat untuk menjajakan produk-produknya.

\section{B. Kegiatan Ekonomi Surabaya dengan Potensi Mangrove}

Banyak sekali jenis tanaman-tanaman yang ada pada ekosistem mangrove yang ada dikota Surabaya, sebagian besar berada di kawasan Pamurbaya dan Pantarbaya. Dengan banyaknya keberagaman tanaman yang ada pada ekosistem mangrove ini, banyak masyarakat yang mulai melakukan pembudidayaan hingga memanfaatkan sumber daya alam yang ada didaerah tersebut menjadi peluang usaha. Tampak pada Gambar 5, 6 dan 7, jenis peluang usaha UKM yang ada pada kawasan Pantarbaya dan Pamurbaya ini diantaranya adalah UKM kerajinan tangan limbah, UKM batik mangrove, UKM produk-produk makanan dan minuman dari mangrove, serta UKM Enceng Gondok [2] [5].

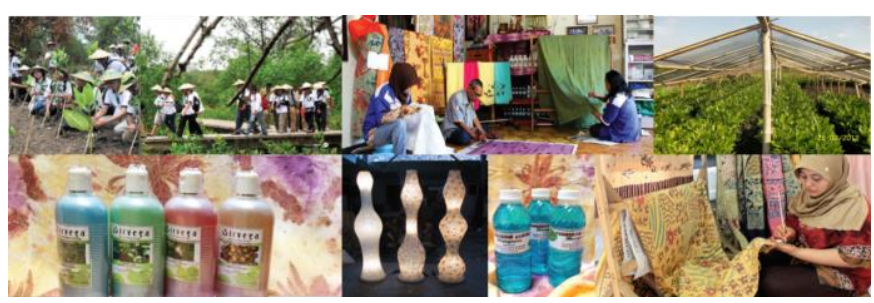

Gambar 5. Kegiatan Komunitas pada Kawasan Eksosistem Mangrove di Surabaya [2]

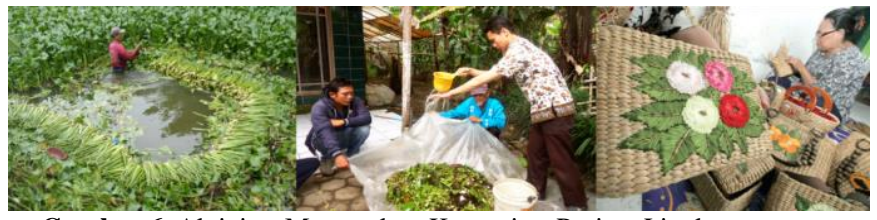

Gambar 6. Aktivitas Masyarakat: Komunitas Pecinta Lingkungan Mengumpulkan Enceng Gondok, Pelaku UKM Rumahan Menjadikannya Sebagai Peluang Usaha [2]

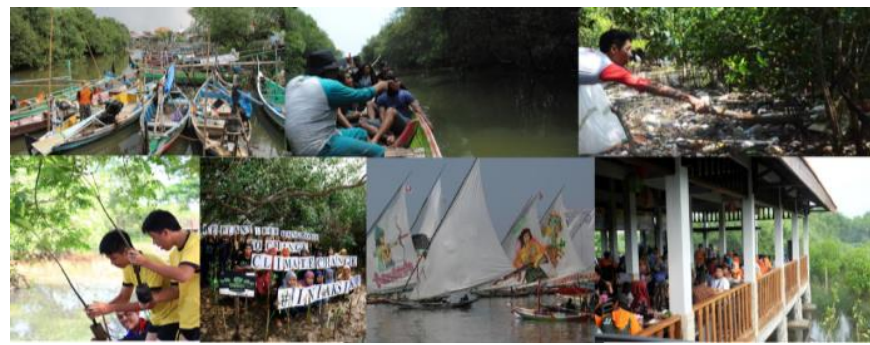

Gambar 7. Aktivitas Masyarakat: Aktivitas Masyarakat Dalam Wacana dan Realisasi Untuk Menghidupkan Kembali Perekonomian Pesisir Surabaya [6]

Selain itu juga terdapat banyak aktivitas masyarakat disekitar area hutan mangrove Pamurbaya dan Pantarbaya yang membuat daerah ini menjadi lebih hidup. Beberapa aktivitas tersebut diantaranya adalah para nelayan mangrove yang berlayar menangkap ikan untuk dijadikan 
konsumsi wisatawan, tourist guide kebun raya mangrove untuk membantu wisatawan berkeliling mengeksplorasi hutan, menanam bibit, dan merawat mangrove. Selain juga terdapat festival bulanan yang diadakan seperti festival kuliner dan jajanan khas sentra mangrove Wonorejo, Festival balap perahu nelayan di kawasan mangrove Kenjeran [6].

\section{Pengolahan Tanah pada Greenery Spot}

Untuk pengolahan tanah, kualitas lapisan tanah perlu diperhatikan. Usaha penggemburan lapisan-lapisan tanah untuk penanaman mangrove perlu dilakukan. lapisan wetland soil yang kurang mendukung harus dicangkul sedalam $30 \mathrm{~cm}$ kemudian tanah tersebut dicampur dengan kompos atau pupuk kandang dan perbandingannya 1:2 atau 1:3 tergantung kebutuhan. Kesuburan tanah sebaiknya memiliki perbandingan fraksi liat, lempung, dan pasir yang seimbang [7].

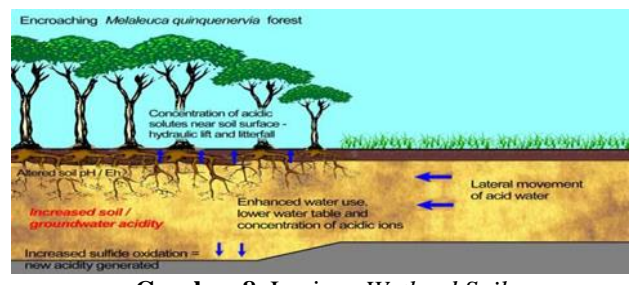

Gambar 8. Lapisan Wetland Soil

Teknik persiapan dan proses pengolahan tanah perlu diperhatikan, antara lain [8]:

- Proses cleaning: dengan pembersihan lapisan tanah dari bibit ataupun akar gulma, sisa-sisa tanaman, dan bebatuan.

- Proses smashing: dengan meremukkan bongkahanbongkahan yang ada pada lapisan tanah yang besar sehingga lapisan menjadi lebih halus dan merata.

- Proses kailyard: dengan pembuatan bedengan. Tanaman mangrove sebaiknya dibudidayakan pada bedengan agar lebih tertata rapi, terutama agar akar tunggang memiliki pondasi untuk berpijak dan berdiri.

\section{Pengolahan Air pada Greenery Spot}
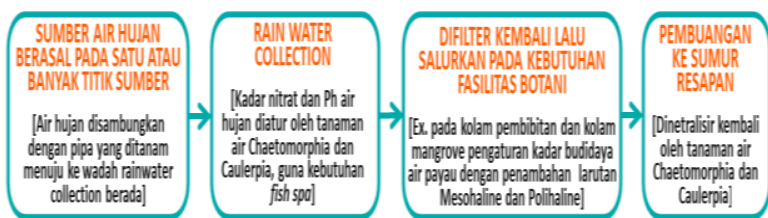

Gambar 9. Bagan Tahap Penggunaan dan Pengolahan Kebutuhan Utilitas Air

Proses pengelolaan air hujan pada kawasan eduwisata dengan menyediakan wadah khusus berupa kolam, sebagai kegunaan berkelanjutan untuk pemenuhan kebutuhan utilitas air pada fasilitas yang ada pada perancangan eduwisata. Pada mangrove greenery spot, tidak semua mangrove ditanam pada area basah, namun ada beberapa mangrove yang ditanam pada area basah, dengan menggunakan air hujan yang telah dibudidayakan menjadi air payau. Namun sebelumnya air hujan telah disimpan dalam bak refugium berupa kolam kecil yang berisi berbagai macam jenis tanaman ekosistem air yang berguna untuk mengurangi kadar nitrat pada air hujan. Tampak pada Gambar 10, jenis tanaman yang digunakan adalah chaetomorphia dan caulerpia. Tanaman air ini juga digunakan sebagai penyaring gray and black water dari kolam air payau, sebelum dilepaskan pada instalasi sumur resapan [9].

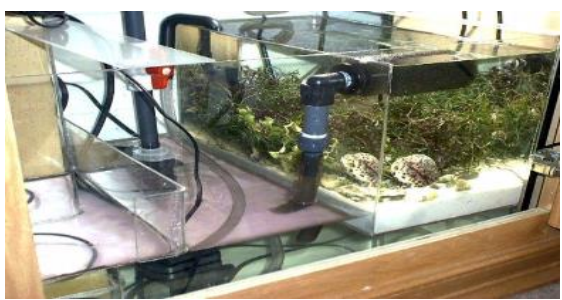

Gambar 10. Sistem Pengolahan Air Refugium pada Gubahan Mangrove Air

Dalam budidaya air payau, kandungan campuran air yang digunakan untuk menciptakan air yang ada pada ekosistem air payau mangrove, yakni dengan mencampurkan bahan Mesohaline dengan takaran 3-16 ppt dan Polihaline dengan takaran 16-30 ppt pada air tawar jernih, untuk menciptakan ekosistem air payau khas daerah wetland. Mesohaline dan Polihaline merupakan senyawa larutan garam zat-zat hara dalam laut. Senyawa biologi ini lama-kelamaan akan menghilang dengan sendirinya karena proses penguapan, serta bukan merupakan bahan kimia yang menghasilkan grey water yang tercemar. Hutan mangrove adalah ekosistem yang paling memiliki ketahanan terhadap berbagai cuaca ekstrem, sebab itu hutan mangrove bisa dikembangbiakkan pada belahan bumi manapun baik dinegara 2-4 musim.

\section{E. Pengolahan Humidity dan Aeration pada Greenery} Spot

Humidity (kelembaban) dan aeration (aerasi) merupakan proses yang diperlukan agar udara pada greenhouse tetap terjaga, terutama dalam ruang indoor planting yang panas, udara dapat menjadi sangat kering. Penanaman mangrove dengan teknik indoor planting harus dijaga tingkat aerasi kelembapannya sebesar 40$60 \%$ sama seperti tanaman hutan hujan tropis pada umumnya [8].

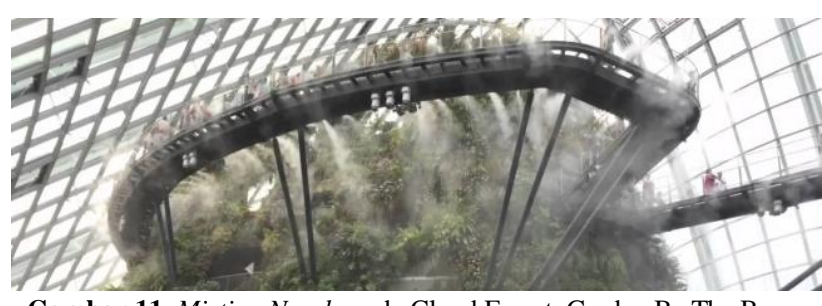

Gambar 11. Misting Nozzle pada Cloud Forest, Garden By The Bay Singapura

Salah satu cara memudahkan meningkatkan tingkat kelembaban di area sekitar taman adalah dengan teknik misting, atau yang biasa dikenal 'embun dingin' seperti yang tampak pada Gambar 11, dengan sebuah alat yang mendukung teknik menyemprot, seperti pipa semprot taman (nozzle) yang baik untuk melembabkan daun dan permukaan daun pada pagi hari sebelum proses fotosintesis terjadi. Teknik misting juga membantu proses penguapan dan menjaga kelembapan udara, serta menghindarkan tanaman dari debu dan hama. 


\section{HASIL DAN PEMBAHASAN}

\section{A. Konsep Bound To Nature}

Perancangan ini dirancang dengan konsep Bound to Nature yang memiliki arti keterikatan dengan alam, dimana desain perancangan akan menggunakan material sisa, material ramah lingkungan, menghadirkan suasana lebih dekat dengan alam, serta menggunakan energi yang ada disekitar site existing. Dengan juga turut menghadirkan nilai edukasi, rekreasi dan interaksi, selain juga menampilkan nilai lokal konten dan mensejahterakan masyarakat lokal di dalam perancangan interior Mangrove Edu-Tourism Centre. Tampak pada Gambar 12, terdapat 4 pilar konsep sustainable yang menjadi penunjang parameter aktivitas, yakni;

- Sustainable Natural Environment: dengan memanfaatkan energi yang ada pada site eksisting,

- Sustainable Influence the Social: dengan menfasilitasi kebutuhan pengguna baik staff mauun pengunjung,

- Sustainable Aspect of building: yakni teknologi yang ada ada bangunan perancangan penunjang aktivitas edukasi, rekreasi dan interaksi, dan

- Sustainable Economy: memperhatikan material yang tahan lama dan mudah dirawat serta dengan harga terjangkau.

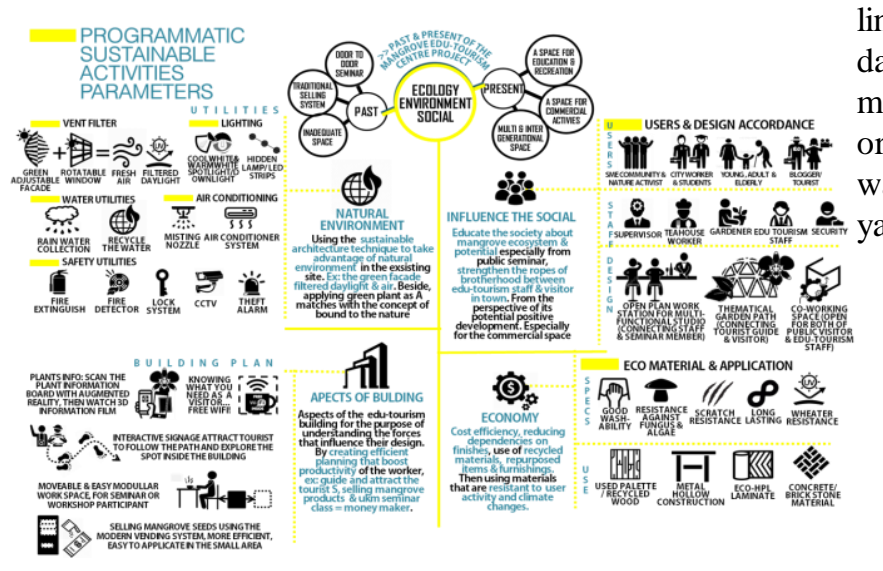

Gambar 12. Bagan Konsep Sustainable Activities Parameters

\section{B. Penerapan Turunan Konsep}

1. Bentuk

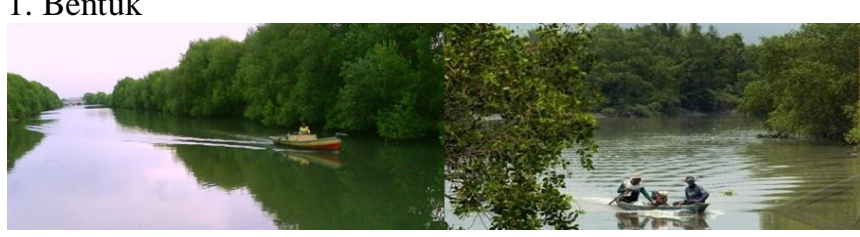

Gambar 13. Kelok Sungai Wonokromo dan Sungai Wonorejo Sumber: https://hariansurya.co.id/HabiburRohman

- Bentuk Dinamis, menggunakan salah satu kenampakan alam pada ekosistem mangrove di Pamurbaya dan Pantarbaya. Dengan menggunakan kedinamisan sungaisungai hilir berair payau setempat, seperti yang tampak pada Gambar 13.

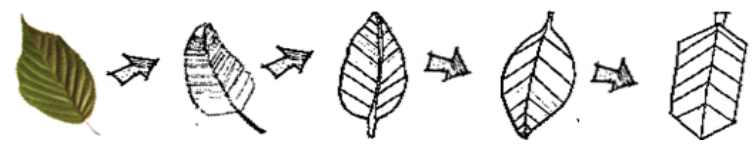

Gambar 14. Stilasi Bentuk Tulang Daun Mangrove

- Bentuk Simetris, menggunakan salah satu kenampakan biodiversitas pada ekosistem mangrove di Pamurbaya dan Pantarbaya. Dengan menggunakan motif daun mangrove, seperti yang tampak pada Gambar 14.

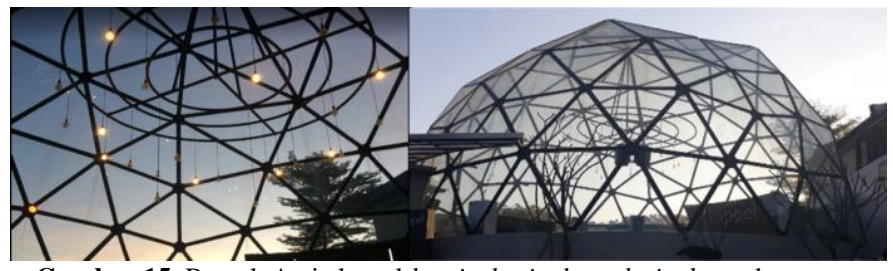

Gambar 15. Bentuk Arsitektural hemispherical geodesic dome dan roof glass.

- Bentuk Arsitektural, menggunakan stilasi bentuk yang sudah ada pada site existing, yakni struktur triangle yang menyatu menjadi bentuk hexagon pada hemispherical geodesic dome dan roof glass seperti yang tampak pada Gambar 15.

\section{Warna}

Pemilihan warna mengambil konsep 'Mimic Colour', yaitu memimik atau meniru warna yang senada dengan lingkungan disekitarnya, seperti fasad, elemen eksterior dan beberapa elemen interior yang menggunakan warna material alami. Selain itu juga diselipkan warna-warna ornamental sebagai aksentuasi warna yang menggunakan warna-warna yang sama dalam branding logo, seperti yang tampak pada Gambar 16.

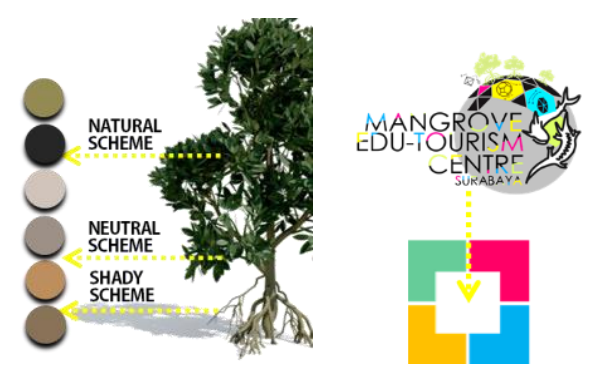

Gambar 16. Mimic Colour Sebagai Warna Dominan dari Stilasi Warna Mangrove, Warna Branding Logo Hadir Sebagai Accent Color

Material

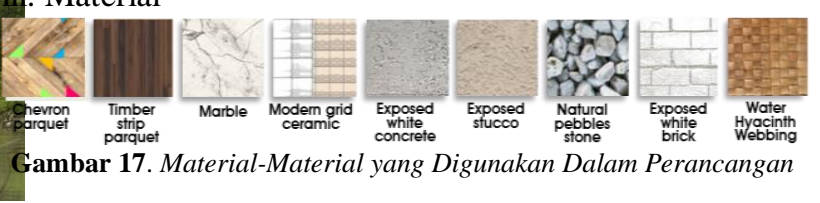

Tampak pada Gambar 17, terlihat jenis material yang digunakan adalah bahan alami, yang memiliki tekstur, bersifat hangat, berkarakter tropis, dan material lokal dari Jawa Timur, seperti eco-block produksi kota Gresik, material kayu anyaman rotan dan enceng gondok dari UKM di Surabaya, serta kayu sisa bekas pakai industri mebel di kota Surabaya. 


\section{Implementasi Konsep}

1. Organisasi Ruang

\section{- Layout}

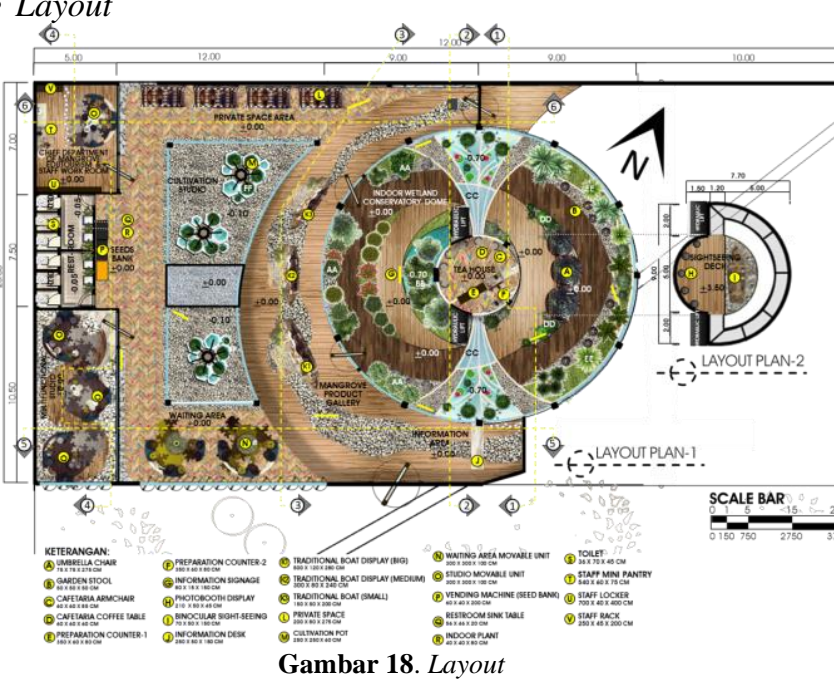

Tampak pada Gambar 18, ruang tidak banyak sekat menyesuaikan dengan karakter alam terbuka diharapkan pengunjung dapat lebih berinteraksi satu sama lain didalamnya. Komposisi perabot pun diletakkan secara free flow, sesuai dengan gambaran sirkulasi yang ada.

\section{- Sirkulasi}

Sirkulasi dibuat mengalir atau free flow, agar pengunjung lebih bebas bereksplorasi. Serta dapat mengarahkan pengunjung untuk lebih mengetahui seluk beluk didalam Perancangan ini. Berasal dari konsep aliran hilir sungai, yang melewati area hutan hujan mangrove kawasan Pamurbaya dan Pantarbaya. Namun, bagi pengunjung yang berkebutuhan khusus dan anak-anak, tourist guide dan Edu-Tourism staff hadir dan siap memandu mereka dalam mengeksplorasi Mangrove EduTourism Centre ini.

\section{Elemen Pembentuk Ruang}

- Lantai

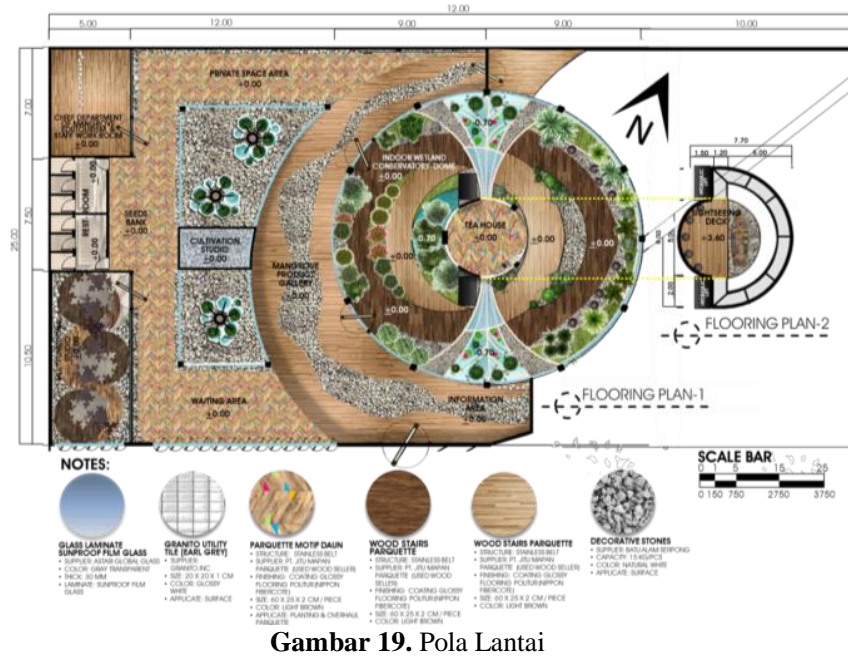

Tampak pada Gambar 19, menggunakan pola lantai yang mengalir, yang mengarahkan pengunjung, yang berasal dari aliran hilir sungai yang ada di hutan hujan mangrove kawasan Pamurbaya dan Pantarbaya. Material menggunakan material yang berbahan dari alam seperti parket dan batu alam.

- Dinding

Beberapa dinding menggunakan dinding kaca transparan untuk menciptakan kesan luas dan aktivitas yang lebih terkoneksi antar setiap ruang. Beberapa sekat digunakan untuk menggambarkan suasana pepohonan di dalam hutan hujan mangrove kawasan Pamurbaya dan Pantarbaya. Pola dinding banyak menggunakan dinding dengan bukaan, memanfaatkan pencahayaan alami yang masuk. Untuk ornamen menggunakan batuan-batuan alam, potongan kayu sisa yang sudah tidak terpakai, vertical garden, agar lebih mendekatkan kesan ruangan dengan konsep kedekatan dengan alam.

\section{- Plafon}

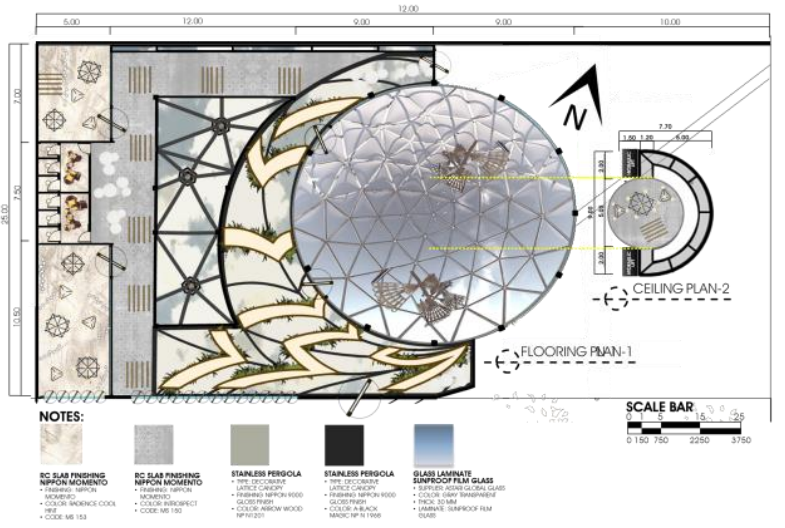

Gambar 20. Pola Plafon

Tampak pada Gambar 20, pola plafon tersusun dari banyak elemen garis, dengan stilasi bentuk tulang daun dan hemisperical geodesic dome structure. Sebagian besar material plafon menggunakan material double glass canopy dan glass dome, karena sekitar $80 \%$ plafon pada site existing menggunakan bahan tersebut.

\section{Elemen Pengisi Ruang} - Perabot

Finishing perabot menggunakan finishing yang menonjolkan karakter bahan: sederhana, dinamis, simetris, ringan (tidak masif). Material yang digunakan adalah material yang tahan cuaca, alami, dan berserat bagus (kayu). Dengan orientasi desain yang mengalir seperti mengikuti alur sirkulasi yang ada.

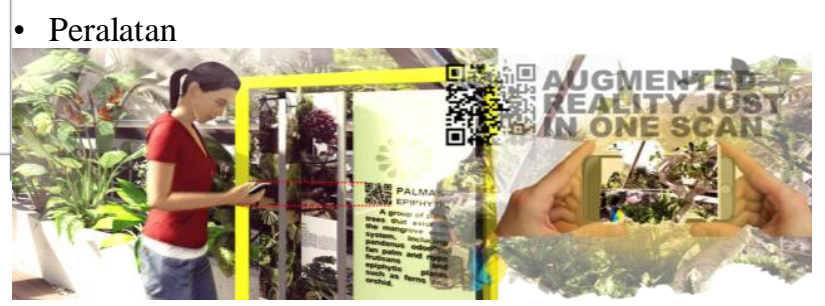

Gambar 21. Scanning Barcode Dengan Teknonologi Augmented Reality

Tampak pada Gambar 21, perancangan menggunakan teknologi Augmented Reality yang dapat menarik pengunjung melalui cara penyampaian edukasi yang berbeda pada setiap signage information board yang ada disetiap sudut area. 


\section{Elemen Tata Kondisional Ruang}

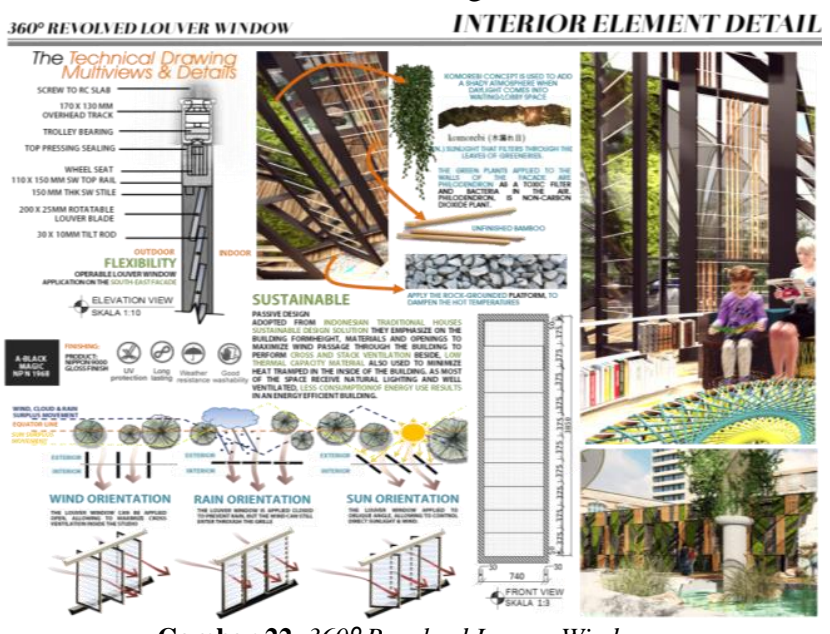

Gambar 22. 360ํำ Revolved Louver Window

\section{- Pencahayaan}

Tampak pada Gambar 22, perancangan banyak menggunakan pencahayaan alami, memanfaatkan kondisi eksisting berupa jendela pivot, sehingga cahaya masuk dari celah jendela seperti hutan tropis, ditambah dengan adanya sistem double facade sebagai penyaring debu dan cahaya matahari, agar udara dan cahaya yang masuk tetap terfiltrasi dan disesuaikan dengan kebutuhan pengguna.

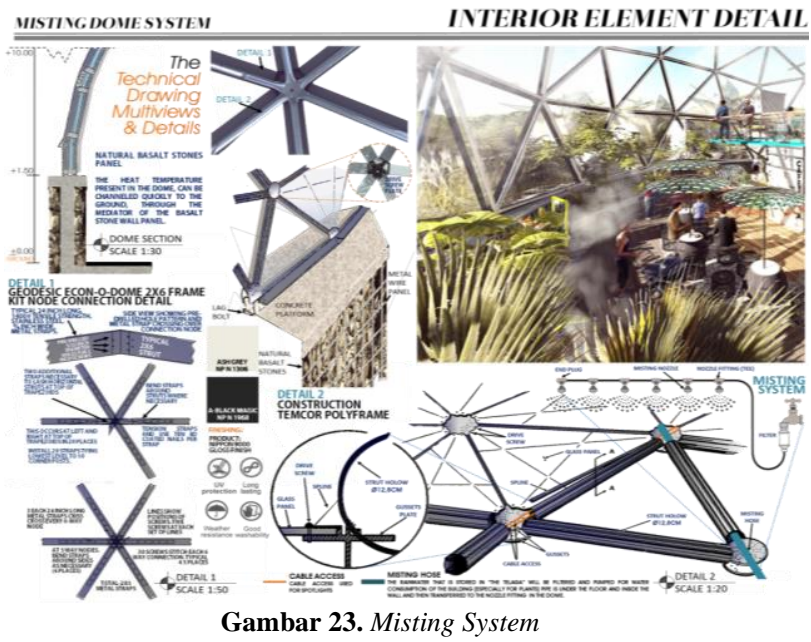

- Penghawaan

Tampak pada Gambar 23, perancangan menggunakan sistem penghawaan buatan dari eksisting bangunan yaitu dengan misting nozzle, dengan adanya embun dingin dapat mengurangi hawa panas yang terkepung dibagian atas dome, sementara itu udara panas didorong mengarah ke area tumbuhan untuk membantu proses pertumbuhannya.

\section{- Dekorasi}

Dekorasi menggunakan banyak elemen-elemen tekstur dan pola pattern yang ada dialam, seperti pola tekstur batang kayu, dekorasi permainan dinding bata, dan masih banyak dekorasi lainnya berupa display tentang mangrove products yang menggunakan display kapal tradisional masyarakat setempat.
- Sistem Proteksi Kebakaran

Proteksi kebakaran pada karya ini menggunakan smoke detector, heat detector, tabung APAR berupa $3 \mathrm{~kg}$ fire extinguisher, water hydrant standart APAR untuk public space, serta sistem misting nozzle.

\section{- Sistem Proteksi Keamanan}

Umum, dengan menggunakan CCTV, menggunakan penjagaan tenaga manusia (security), dikarenakan untuk keamanan display gallery dan tanaman pada Indoor Wetland Conservatory Dome. Untuk menghindari pencurian, pemetikan dan merusak tanaman.Sementara itu Keamanan Area UKM Mangrove Product Gallery, dengan menggunakan sistem alarm jangkauan gadget dari sensor di pintu keluar dan juga sensor key yang dipasang pada setiap produk yang dipajang.

\section{Desain Akhir}

\section{Main Entrance}

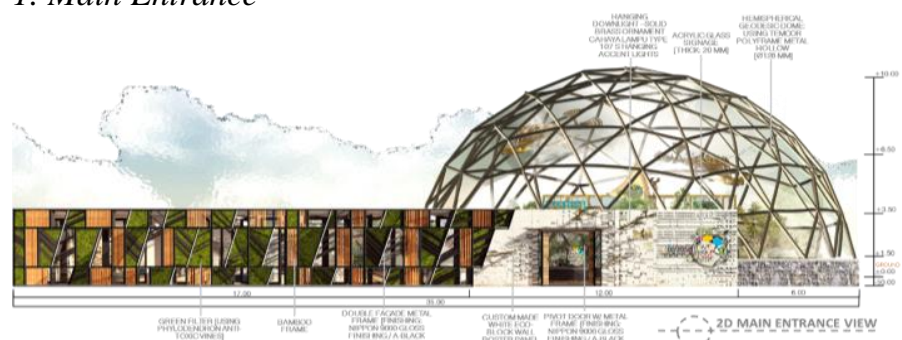

Gambar 24. Main Entrance

Tampak pada Gambar 24, area Main Entrance menyajikan desain yang futuristik namun tetap menggunakan material lokal, seperti penggunaan material bambu, batu alam, dan ecoblock Gresik pada bagian main entrance facade. Untuk area dome tetap mengekspos kaca dome yang terbuka, agar pengunjung diluar bangunan dapat merasakan atmosfer apa yang akan dilihat didalam.

\section{Perspektif Desain}
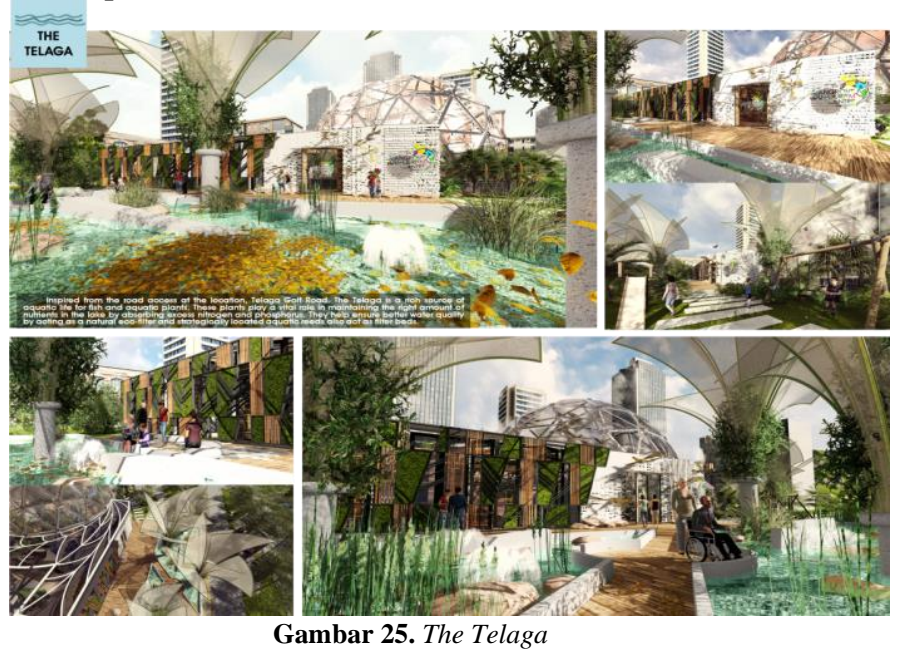

Tampak pada Gambar 25, area The Telaga Park and Pond, adalah sumber kehidupan akuatik yang kaya dari ikan garra rufa (doctor fish) dan alang-alang chaetomorphia dan caulerpia, yang memainkan peran penting dalam menjaga jumlah nutrisi yang tepat di telaga dengan menyerap kelebihan nitrogen dan fosfor pada air 
hujan. Mereka membantu memastikan kualitas air yang lebih baik dengan bertindak sebagai eco-filter alami dan alang-alang air sangat berguna juga sebagai pengatur $\mathrm{PH}$ air.

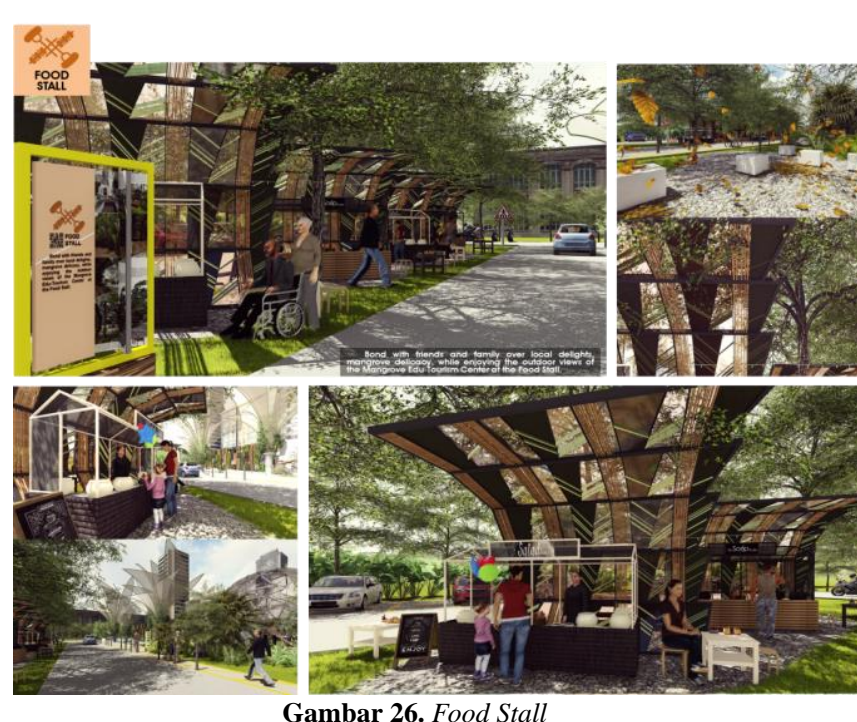

Tampak pada Gambar 26, area Food Stall yang digunakan untuk menarik perhatian pengunjung ketika baru datang ke Mangrove Edu-Tourism Centre. Food Stall menjual produk-produk makanan khas mangrove, produk makanan yang dijual pada area ini adalah produk makanan berat.

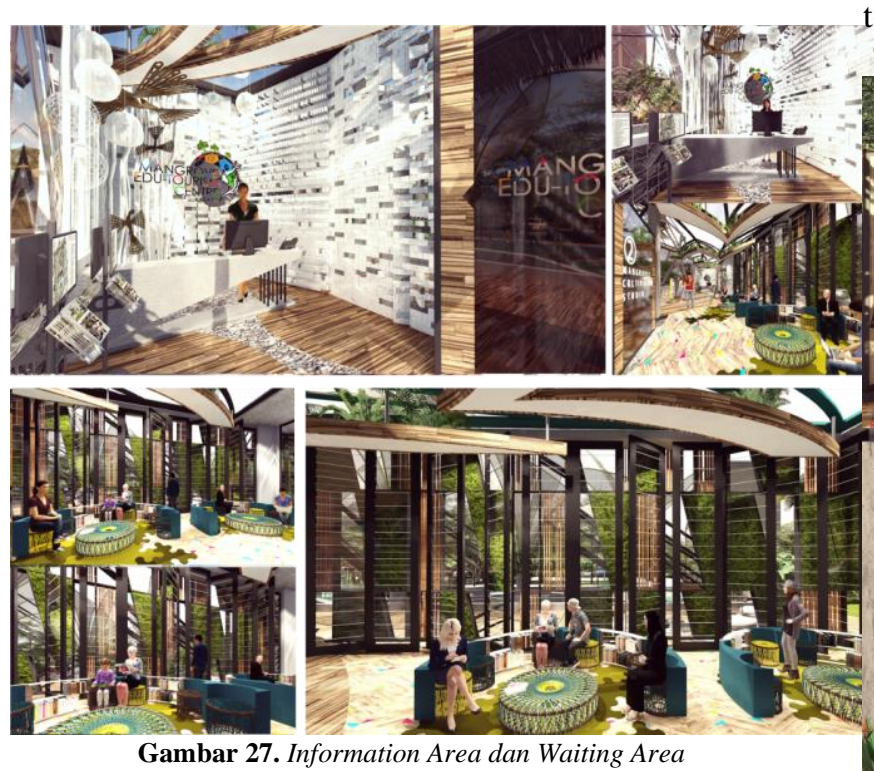

Tampak pada Gambar 27, Service unit hadir dengan information area untuk memberikan informasi serta pembelian tiket masuk bagi pengunjung. Waiting area untuk tempat duduk atau menunggu, terutama pengunjung yang ingin menunggu jadwal studio. Pada waiting area terdapat juga beberapa display buku-buku mangrove, agar pengunjung juga dapat teredukasi dengan adanya buku-buku bacaan ini.

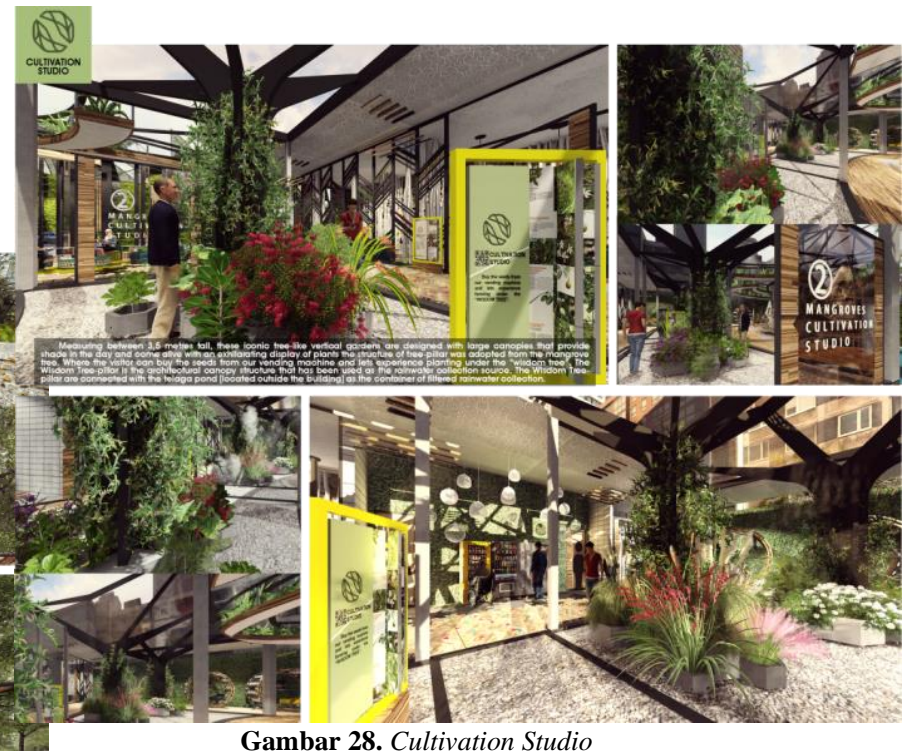

Tampak pada Gambar 28, area Cultivation Studio didesain untuk publik, agar mereka dapat teredukasi dan turut berinteraktif dalam menyelamatkan lingkungan, dengan melalui penanaman bibit, serta perawatannya. Cultivation Studio menggunakan struktur rangka treepillar yang menggunakan sususan baja yang diikat, dimana dibagian tengah pillar terdapat rongga untuk tempat aplikasinya pipa. Struktur canopy kaca diatasnya dibuat agak mengerucut kebawah, agar mendukung masuknya air hujan kedalam pipa yang terhubung di telaga (kolam buatan yang ada di luar bangunan).

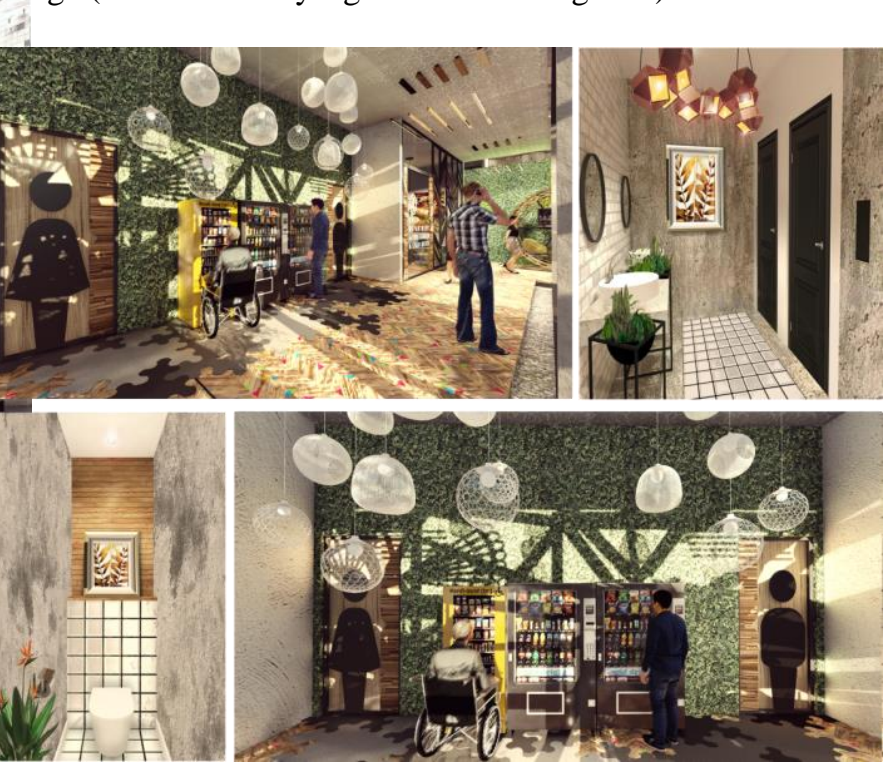

Gambar 29. Seeds Bank dan Restroom

Tampak pada Gambar 29, area Seeds Bank diletakkan berbedakatan dengan area cultivation studio, supaya pengunjung yang ingin melakukan pembibitan dapat dengan mudah membeli bibit mangrovemelalui vending machine yang terdiri dari 2 mesin yang satu untuk pengguna universal (vending machine warna hitam) dan yang satu lagi untuk pengguna kursi roda (vending machine warna kuning). 


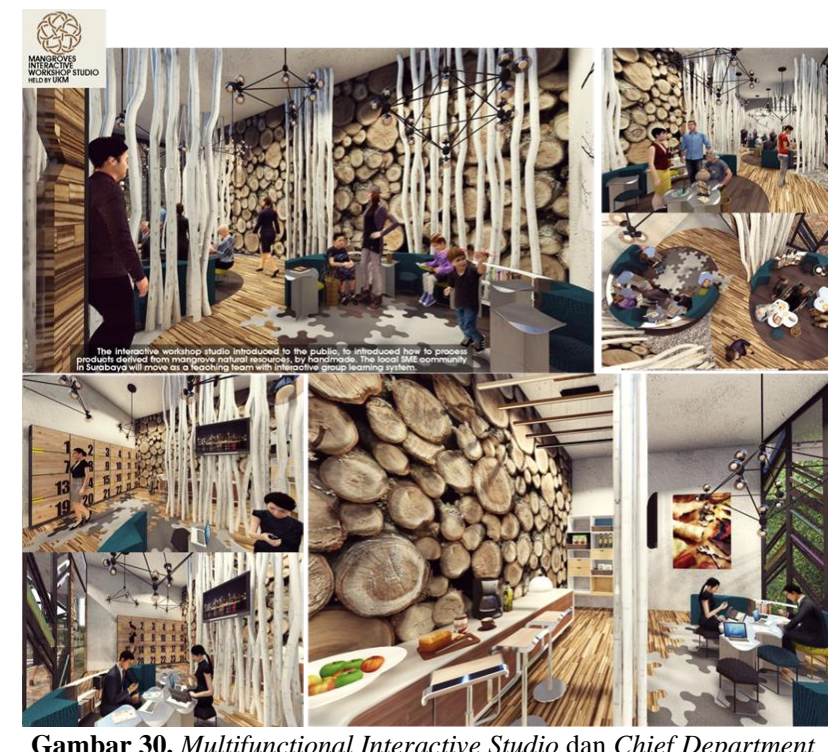

Gambar 30. Multifunctional Interactive Studio dan Chief Department of Edu Tourism and Staff Work Space

Tampak pada Gambar 30, area Multifunctional Interactive Studio digunakan untuk memberikan penyuluhan dan pengajaran tentang ekosistem mangrove, pengolahan potensi mangrove dan cara-cara pembibitan serta perawatannya. Dengan melalui adanya acara-acara seminar dan workshop interaktif, dengan tujuan agar pengunjung juga ikut turut serta dan mengetahui cara pembuatan produk-produk pengembangan hasil sumber daya alam ekosistem mangrove oleh para UKM yang ada dikawasan Pamurbaya dan Pantarbaya.

Penggunaan meja dan kursi yang movable dimaksudkan agar pengguna dapat dengan mudah memindahkannya antara satu tempat ke tempat yang lainnya, mengingat dalam realisasinya, pengajaran dalam seminar dan workshop interaktif nantinya akan diterapkan dalam sistem belajar bersama atau belajar kelompok. Selain juga dapat mempererat koneksi antar pengunjung dan juga edu-tourism staff yang berperan sebagai pengajar. Chief Department of Edu Tourism Space merupakan kantor pusat bagi seluruh edu-tourism staff.

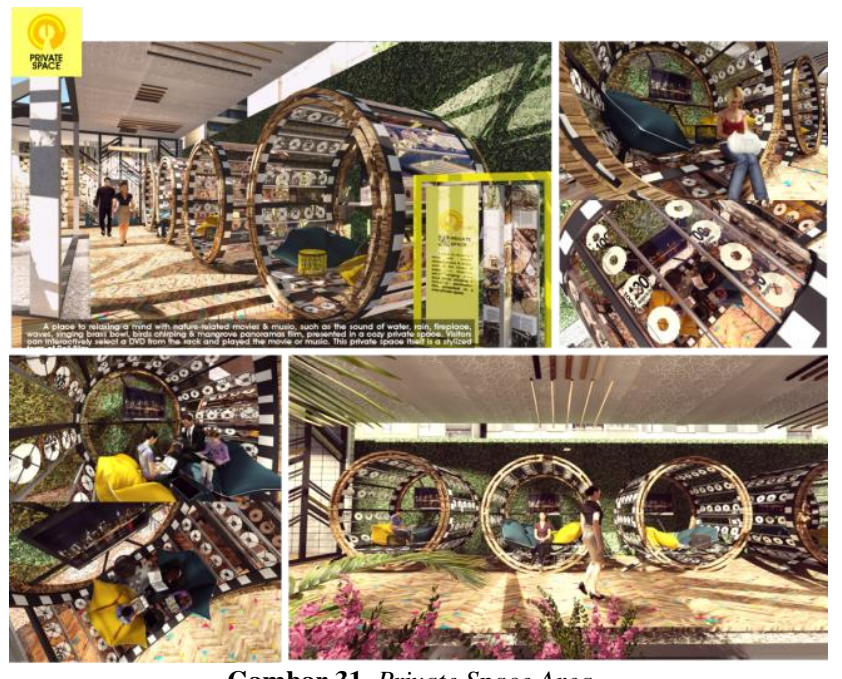

Gambar 31. Private Space Area

Tampak pada Gambar 31, Private Space area adalah tempat untuk menenangkan pikiran dengan film \& musik yang berhubungan dengan alam, seperti suara air, hujan, perapian, ombak, nyanyian mangkuk kuningan, kicau burung dan film panorama mangrove, disajikan di ruang pribadi yang nyaman. 
yang rindang, dan elemen tradisional lainnya memiliki efek yang menghibur dan meningkatkan daya ingat mereka.

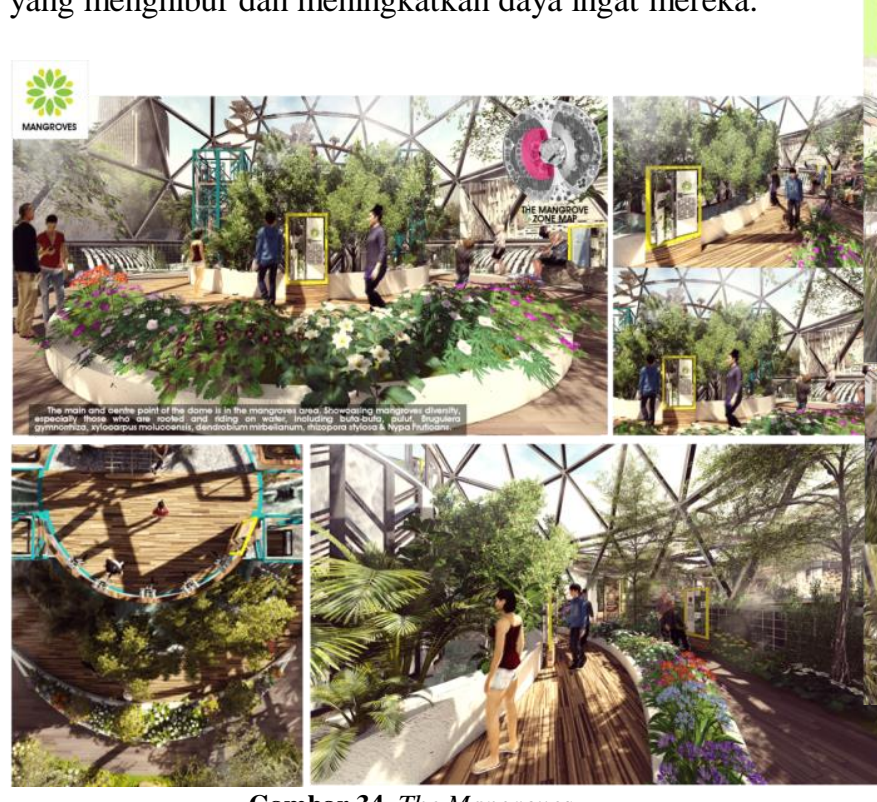

Gambar 34. The Mangroves

Tampak pada Gambar 34, area The Mangroves merupakan titik utama dan pusat kubah berada di area mangrove. Menampilkan keanekaragaman mangrove, terutama yang berakar dan menunggangi air, termasuk buta-buta, pulut, Bruguiera gymnorrhiza, Xylocarpus moluccensis, Dendrobium mirbelianum, Rhizopora stylosa dan Nypa Fruticans.

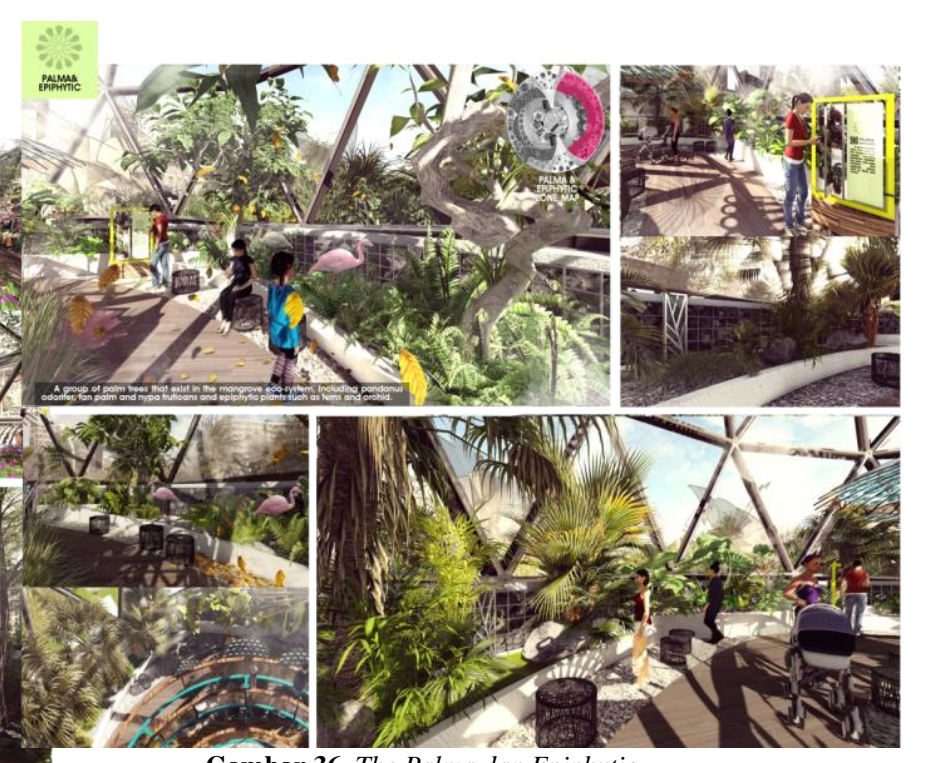

Gambar 36. The Palma dan Epiphytic
Tampak pada Gambar 36, area The Palma and Epiphytic adalah sekelompok pohon palem yang ada di ekosistem mangrove, termasuk pandanus odorifer, palem kipas dan nypa fruticans dan tanaman epifit seperti pakis dan anggrek. Pada area ini juga terdisplay beberapa fauna yang ada pada hutan mangrove kawasan Pamurbaya dan Pantarbaya. Pajangan fauna ini merupakan patung yang dibuat menyerupai aslinya. Dengan kegunaan agar pengunjung juga mengetahui ekosistem apa saja yang ada didalam hutan mangrove.

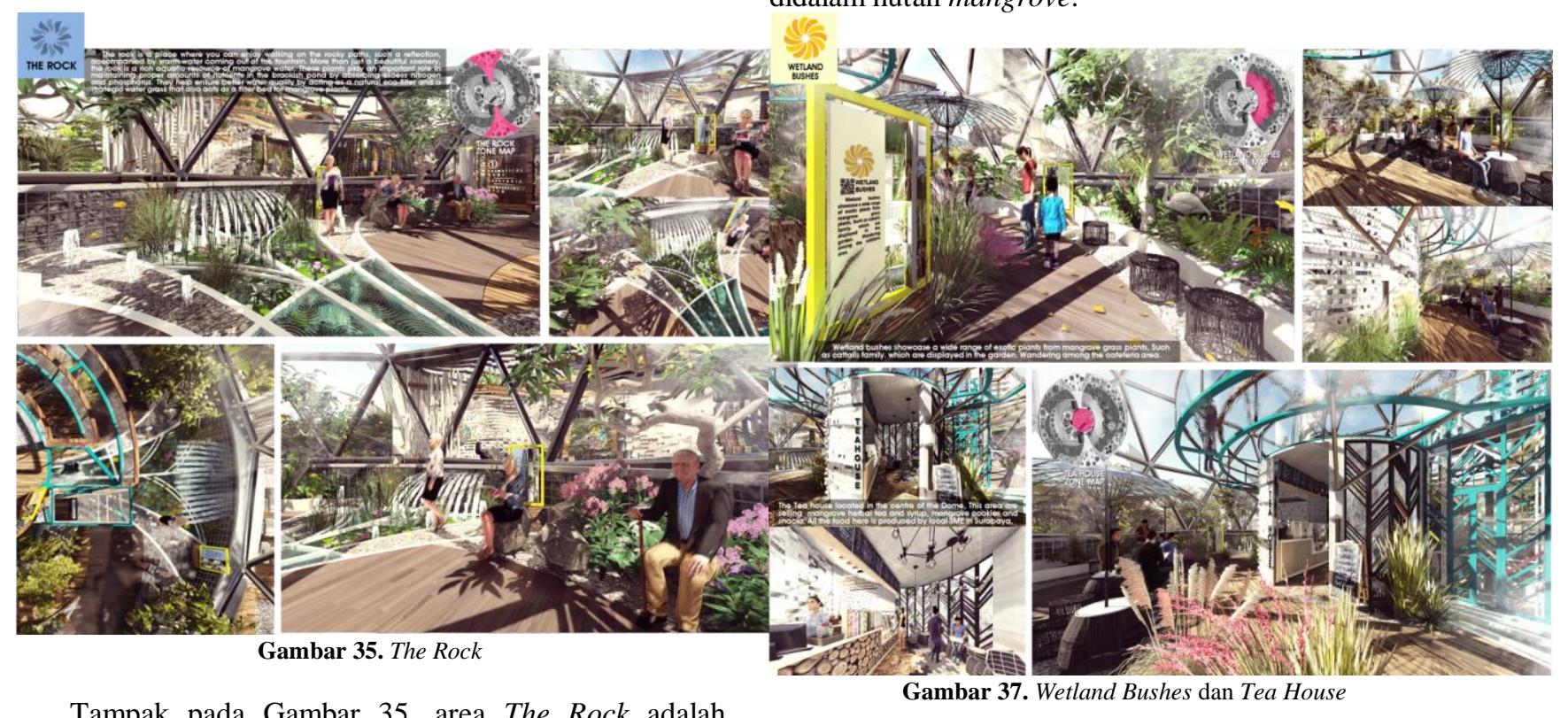

Tampak pada Gambar 35, area The Rock adalah tempat dimana Anda dapat menikmati berjalan di jalan berbatu, refleksi seperti itu, disertai dengan air hangat yang keluar dari air mancur. Lebih dari sekedar pemandangan yang indah, batu karang adalah sumber air akuatik yang kaya air mangrove. Tanaman ini memainkan peran penting dalam menjaga jumlah nutrisi yang tepat di kolam payau dengan menyerap kelebihan nitrogen dan fosfor. Mereka membantu memastikan kualitas air yang lebih baik dengan bertindak sebagai eco-filter alami dan rumput air strategis yang juga bertindak sebagai alas penyaring untuk tanaman mangrove.
Tampak pada Gambar 37, area Wetland bushes menampilkan berbagai macam tanaman eksotis dari keluarga tanaman rumput yang ada pada ekosistem mangrove, seperti keluarga cattails (kapok semak) yang ditampilkan di sekitar area tea house. Tea house merupakan area culinary yang menjual produk teh mangrove, sirup mangrove dan beberapa kudapan ringan mangrove dengan sistem takeaway counter. 


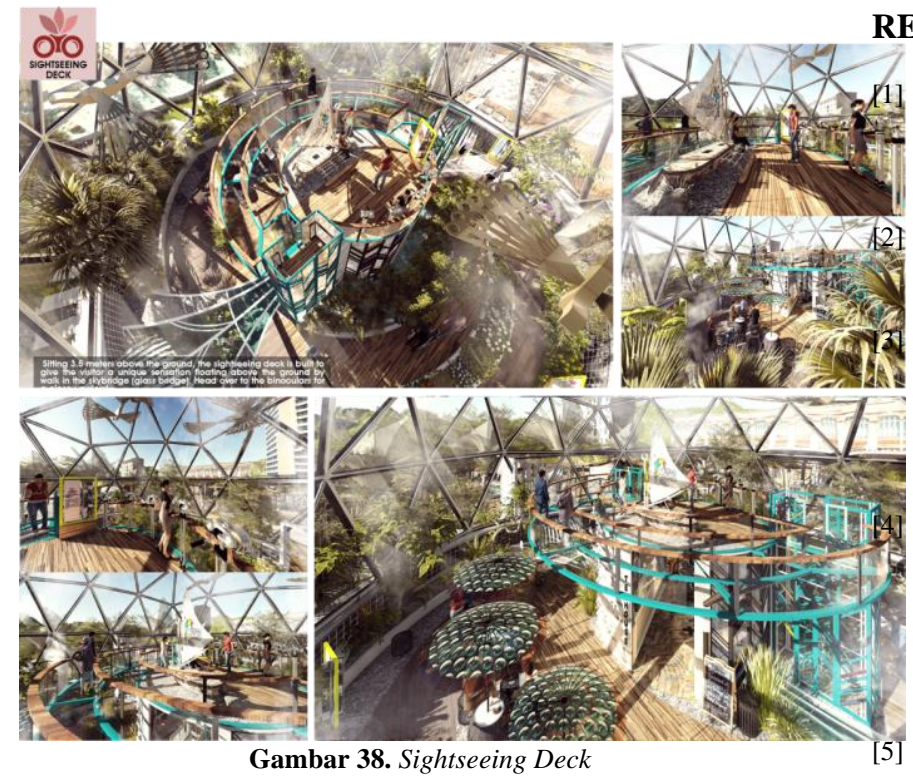

Tampak pada Gambar 38, area Sightseeing Deck terbagi menjadi 2 bagian yakni binocular area dan juga skybridge. Skybridge merupakan jembatan kaca transparan untuk melihat-lihat pemandangan dan kondisi sekitar ekosistem mangrove yang ada pada indoor wetland conservatory dome, dengan sensasi berjalan diatas ketinggian. Selain terdapat binocular camera, yakni selain juga digunakan untuk mengetahui kondisi cuaca disekitar gedung.

\section{SIMPULAN}

Implementasi konsep Bound To Nature pada Perancangan Interior Mangrove Edu-Tourism Centre di Surabaya ini diharapkan dapat mendukung terciptanya sebuah wadah alternatif yang solutif dan berbeda dari perancangan sebelumnya yang ada. Perancangan ini diyakini dapat memberikan program edukatif, rekreatif dan interaktif dengan cara yang baru, mampu menarik masyarakat lokal maupun dunia untuk datang dan menjadikannya tujuan destinasi yang baru, merasakan lokal konten dari kawasan mangrove Pamurbaya dan Pantarbaya. Serta berkesinambungan dengan konsep edutourism yakni melestarikan lingkungan dan mensejahterahkan masyarakat daerah dan UKM setempat.

Setelah melalui proses perancangan yang panjang, selaku perancang atas Perancangan Interior Mangrove Edu-Tourism Centre di Surabaya ini merasa bahwa tidak ada perancangan yang sempurna didunia ini. Namun yang diharapkan oleh perancang adalah:

- Bagi penulis dan perancang interior sejenis berikutnya untuk dapat menjadikan jurnal ini sebagai contoh dan pedoman wawasan untuk memahami proyek perancangan dengan basis edu-tourism yang peduli terhadap kelangsungan kawasan hutan lindung serta memperkenalkan potensinya.

- Bagi ilmu desain interior dan peneliti selanjutnya, agar dapat memahami bagaimana pembangunan wadah perancangan berbasis edu-tourism yang sesuai dengan konsep edukatif, rekreatif, interaktif, lokal konten serta mensejahterahkan masyarakat daerah.

\section{REFERENSI}

Giri, Chandra P. Remote Sensing of Land Use and Land Cover: Principles and Applications. Boca Raton: CRC Press (Taylor \& Francis Group), 2012.

Fikser, Muhammad. Buku Mangrove Surabaya. Surabaya: Online Publicity, 2016.

Dilts, Robert. Tools for Dreamers: Strategies for Creativity and the Structure of Innovation (2nd Publish, originally 1991). Santa Cruz: Dilts Strategy Group, 2017.

Direktorat Produk Pariwisata, Direktorat Jenderal Pengembangan Destinasi Pariwisata, Departemen Kebudayaan dan Pariwisata dan WWF-Indonesia. Prinsip Dan Kriteria Eduwisata Berbasis Masyarakat. Jakarta, 2009.

[5] Mulyani, Lulut Sri. Personal conversation interview. 21 Sep. 2017.

[6] Farid Kamal Muzaki, et al. Menjelajah Mangrove Surabaya. Surabaya: Pusat Studi Kelautan LPPM Institut Teknologi Sepuluh November, 2017.

[7] Isman. Personal conversation interview. 19 Sep. 2017.

[8] Castilla, Nicolas. Greenhouse Technology and Management 2nd Edition. Boston: CABI, 2013.

[9] Koh, Buck Song. Perpetual Spring, Singapore's Gardens by the Bay. Singapore: Marshall Cavendish Editions, 2012.

[10] Dinas Lingkungan Hidup Surabaya. Profil Keanekaragaman Hayati (Kehati). Surabaya: Kehati, Dinas Lingkungan Hidup Surabaya, 2011. 